\title{
TYMS wt Allele
}

National Cancer Institute

\section{Source}

National Cancer Institute. TYMS wt Allele. NCI Thesaurus. Code C51047.

Human TYMS wild-type allele is located in the vicinity of $18 \mathrm{p} 11.32$ and is approximately 16

$\mathrm{kb}$ in length. This allele, which encodes thymidylate synthase protein, is involved in

maintenance of the thymidine-5'-monophosphate (dT MP) pool necessary for DNA

replication and repair. Certain allelic variants of the TYMS gene confer resistance to chemotherapy. 